\title{
THE INFLUENCE OF ECONOMIC CRISIS ON THE INTERNATIONAL POSITION OF THE EURO
}

The drive to stabilise and facilitate the functioning of international monetary system was one of the reasons why various entities have decided to participate in monetary initiatives whose aim was to create several regional monetary unions. However, it seems that those benefits of monetary integration, though recalled so often, are just additional bonuses, as it is the possibility of individual gains, including gains in prestige, which seems to be of prime importance. At the same time, the risks caused by the increasingly frequent crises weaken the interest of particular states in monetary union and the support for the idea of solidarity that is fundamental to any monetary union. It has been visible in the case of Economic and Monetary Union. It was expected that the introduction of the new regional currency - the euro - would create a real alternative to the US dollar as the euro would become an international currency both in official and private spheres.

Those expectations were fulfilled in the first years of the euro's existence. In a relatively short time, the common European currency became the second international currency, which fuelled speculations that it may soon become the international currency number one. The supporters of the thesis of the euro's imminent rise pointed out the specific structure of the Economic and Monetary Union and its growth prospects. The financial and economic crisis that began in the United States according to many provided yet another very important piece of evidence supporting the claims of the growing importance of the euro. However, in the subsequent years the international situation didn't change as the euro-optimists had expected. What is more, the weaknesses and lack of cohesion of the euro area became more visible, and so did the methodological faults in the construction model of the monetary union. In consequence, the optimistic views on the euro's perspectives were slowly replaced by visions of a breakup of the EMU and the fall of the new currency. However, in recent years we have seen that in short- and mid-term perspectives both optimists and pessimists were mistaken. This means that under global and regional instability we have arrived at a relative stabilisation on the monetary market, thus reaching a point to which the new monetary order headed for a long time. The chaos was replaced by order. 
A currency becomes international, if it fulfils classic functions of money - measuring and storing value, as well as being a medium of payment - not only internally but also internationally. What is more, those functions must be fulfilled both in the official and private spheres. In the official sphere, to be considered international a currency should be used by third states as a reference currency, intervention currency and reserve currency, and in the private sphere a currency should be used for invoicing, transfer and investment ${ }^{1}$. It needs to be stressed that all those functions are interconnected and must be fulfilled by a currency simultaneously.

An entity - a state or a union of states - that issues a currency must meet certain political and economic conditions to enable its currency to aspire to becoming and to possibly become an international currency. The economic conditions include structural factors and economic policy. Structural factors usually include the volume of production and commerce and the size of the financial market of the issuer. The higher the share of the currency-issuing entity in the global output and international commerce, the higher the probability and therefore the possibility that entities from other states will use its currency for invoicing and paying, and the higher the possibility that monetary authorities of third states will use that currency as reference, reserve and intervention currency. The possibilities that entities from other states will use the currency as a transfer and investment currency and that monetary authorities of third states will use that currency as a reserve and intervention currency increase with the size of the financial market of the issuing state ${ }^{2}$.

Taking all the above into account, we may wonder whether structural factors benefited the euro as an important international currency and whether the subsequent years had influenced its position. According to the International Monetary Fund's data, in 2001 the share of 12 euro area member states in the global GDP (PPP) was $15.9 \%$ while that of the USA was $21.4 \%$. The euro area's share in international export of goods and services - including trade within the area - in the same year equalled $30.3 \%$ compared to $13.6 \%$ of the USA ${ }^{3}$. This might be considered a proof of relatively strong structural foundations of the new regional currency, thus making it possible to claim that the expectations for the success of the new currency issued by the European Central Bank were fully justified. The more so as the dominance of the US dollar among international currencies was very clear, and so were expectations that some kind of alternative to the US currency would come to existence. The euro

${ }^{1}$ Międzynarodowa rola euro III, Departament Integracji ze Strefą Euro, Narodowy Bank Polski, Warszawa 2011, p. 4.

2 Ibidem.

3 World Economic Outlook. Recessions and Recoveries, April 2002, IMF, p. 149. 
could become such an alternative, and thanks to seemingly strong structural foundations and a large credit of trust from the participants in the international monetary system, it had all the possibilities open to become the leading international currency. However, if we consider the eurozone's share in international export of goods and services excluding the trade within the area, the data is no longer so optimistic and it no longer suggests the clear dominance of the new monetary union. In 2001, the eurozone's share in the international export of goods and services was nowhere near $1 / 3$ of global export but just $13.4 \%$.

Table 1. Share in global GDP, export of goods, and population of selected states and unions (in \%)

\begin{tabular}{|c|c|c|c|c|c|c|c|c|c|c|c|c|c|c|c|}
\hline & \multicolumn{5}{|c|}{ GDP (PPP) } & \multicolumn{5}{|c|}{$\begin{array}{l}\text { Export of goods (excluding EU } \\
\text { internal trade) }\end{array}$} & \multicolumn{5}{|c|}{ Population } \\
\hline & 2001 & 2007 & 2010 & 2012 & 2013 & 2001 & 2007 & 2010 & 2012 & 2013 & 2001 & 2007 & 2010 & 2012 & 2013 \\
\hline USA & 21.4 & 21.4 & 19.7 & 18.9 & 19.3 & 13.6 & 9.6 & 9.8 & 9.8 & 9.8 & 4.6 & 4.7 & 4.5 & 4.5 & 4.5 \\
\hline Eurozone & 15.9 & 16.1 & 14.6 & 13.7 & 13.1 & 30.3 & 29.5 & 26.1 & 24.9 & 25.3 & 5.0 & 4.9 & 4.8 & 4.8 & 4.7 \\
\hline Japan & 7.3 & 6.6 & 5.8 & 5.6 & 5.4 & 6.0 & 4.7 & 4.6 & 4.1 & 3.6 & 2.1 & 2.0 & 1.9 & 1.8 & 1.8 \\
\hline $\begin{array}{l}\text { United } \\
\text { Kingdom }\end{array}$ & 3.1 & 3.3 & 2.9 & 2.8 & 2.7 & 5.1 & 4.2 & 3.5 & 3.4 & 3.4 & 1.0 & 0.9 & 0.9 & 0.9 & 0.9 \\
\hline
\end{tabular}

Source: Own work based on: World Economic Outlook. Recovery Strengthens, Remains Uneven, April 2014, IMF, p. 159; World Economic Outlook. Hopes, Realities, Risks, April 2013, IMF, p. 139; World Economic Outlook. Tensions from the Two-Speed Recovery Unemployment, Commodities and Capital Flows, April 2011, IMF, p. 171; World Economic Outlook. Housing and the Business Cycle, April 2008, IMF, p. 235; World Economic Outlook. Recessions and Recoveries, April 2002, IMF, p. 149 AMECO.

In the subsequent years, in the common opinion, the positions of the euro and the EU were getting stronger due to, inter alia, the accession of new member states and the increased cooperation and cohesion, which in turn resulted in strong structural foundations and economic policy. The position of the euro, when compared to its beginnings, was not strengthened: in fact, in many sectors it started to get weaker. The euro and the eurozone have been losing their positions to the US economy and the US dollar, and partly to other developed countries. As stated in Table 1, in 2013 the euro area's (consisting of 17 member states) share in the world's GDP (PPP) was $13.1 \%$, which was 2.8 percentage points lower when compared to 2001, even though the number of member state was larger. During the same period the share of the US GDP in the world GDP also fell, but only by 2.1 percentage points to $19.3 \%$. The share of the euro area and the USA in the international export was respectively $25.3 \%$ and $9.8 \%$. However, the data and therefore the opinion on the share of the international trade in goods and services changes when we look at the euro area using the AMECO data (i.e. when we exclude export inside the EU). When thus 
calculated, as early as 2007, the eurozone's share in the international trade in goods and services was $13.3 \%$, in $2010-12.2 \%$, in $2012-11.5 \%$, and in $2013-11.4 \%$, thus being only slightly higher than the American share. The presented data suggests that after a period of strengthening of the euro area's position and the structural factors of the economy, a seemingly permanent downwards tendency was observed in the subsequent years ${ }^{4}$.

It needs to be stressed that in the recent years the share of the main developed economies (the euro area, United States and Japan) in the world's GDP has fallen and the share of the developing countries, particularly of the BRIC group member states (Brazil, Russia, India and China), has risen. According to the IMF data, the BRIC countries' share in the global GDP (PPP) rose from $21.4 \%$ in 2007 to $24.9 \%$ in 2010, 26.3\% in 2012 and $26.9 \%$ in 2013, and among those China's share in the global GDP (PPP) rose from $10.8 \%$ in 2007 to $13.6 \%$ in $2010,14.9 \%$ in 2012 and $15.4 \%$ in 2013. In the same period (2007-2013), the US share in the global GDP (PPP) fell from $21.4 \%$ to $19.3 \%$, the euro area's share fell from $16.1 \%$ to $13.1 \%$, and Japan's share fell from $6.6 \%$ in 2007 to $5.4 \%$ in 2013 . The increase in the importance of the economies of the developing countries is in part caused by their population. In 2013, the BRIC states were inhabited by $41.8 \%$ of global population (19.3\% in China and $17.7 \%$ in India alone ${ }^{5}$ ). However, some improvement in structural dimension does not correlate with an increase in the global importance of the currencies of those states.

Size, liquidity and the level of the financial markets liberalisation, as well as the level and intensiveness of the capital transfer limits, need to be taken into account when evaluating perspectives of proper fulfilment by the euro of the international function of currency in the structural dimension. According to the data showcased in Table 2, at the beginning the situation of the euro area was relatively good. What is more, considering the data up to 2010 , it was widely held that in a relatively short time the euro would become the dominant international currency and would replace the US dollar. The financial market of the enlarged euro area before 2010, understood as stock market capitalisation, debt securities and bank assets, was larger than in the United States both as absolute value (Table 2) and in proportion to the GDP (Figure 1).

\footnotetext{
${ }^{4}$ Economic and Financial Affairs, European Commission, http://ec.europa.eu/economy_finance/ameco/ user/serie/SelectSerie.cfm (15.05.2014).

5 World Economic Outlook. Recovery Strengthens, Remains Uneven, IMF, April 2014, p. 159.
} 
Table 2. Capital market size: selected indicators (billions of U.S. dollars)

\begin{tabular}{|c|c|c|c|c|c|}
\hline & & USA & Euro area & Japan & United Kingdom \\
\hline \multirow{4}{*}{$\begin{array}{c}\text { Stock market } \\
\text { capitalisation [1] }\end{array}$} & 2001 & 13826.6 & $4276,$. & 2293.8 & 2164.7 \\
\hline & 2007 & 19922.3 & 10040.1 & 4663.8 & 3851.7 \\
\hline & 2009 & 15077.3 & 6576.1 & 3395.6 & 2796.4 \\
\hline & 2012 & 16855.6 & 5845.7 & 3638.6 & 3415.7 \\
\hline \multirow{4}{*}{$\begin{array}{c}\text { Total debt } \\
\text { securities [2]: }\end{array}$} & 2001 & 18504.3 & 9492.1 & 6925.1 & 1748.1 \\
\hline & 2007 & 30324.2 & 23004.2 & 9213.7 & 3841.5 \\
\hline & 2009 & 31646.6 & 26485.7 & 11921.0 & 4710.6 \\
\hline & 2012 & 35191.7 & 21822.9 & 14592.4 & 5778.2 \\
\hline \multirow{4}{*}{ Public } & 2001 & 9698.0 & 4181.3 & 5317.1 & 447.9 \\
\hline & 2007 & 6595.9 & 7606.4 & 7147.7 & 913.5 \\
\hline & 2009 & 9478.2 & 8562.5 & 9657.4 & 1238.5 \\
\hline & $2012^{*}$ & 12874.7 & 8872.2 & 12790.6 & 1613.4 \\
\hline \multirow{4}{*}{ Private } & 2001 & 8806.3 & 5310.8 & 1608.0 & 1300.2 \\
\hline & 2007 & 23 728.,3 & 15397.8 & 2066.0 & 2928.0 \\
\hline & 2009 & 22168.4 & 17923.2 & 2263.6 & 3472.1 \\
\hline & $2012^{*}$ & 20826.2 & 16104.0 & 2578.7 & 3225.8 \\
\hline \multirow{4}{*}{ Bank assets [3] } & 2001 & 22157.4 & 24463.9 & 12408.6 & 7069.0 \\
\hline & 2007 & 11194.1 & 35097.1 & 10086.9 & 11655.0 \\
\hline & 2009 & 14163.1 & 32421.7 & 11042.4 & 11043.9 \\
\hline & 2012 & 14822.5 & 34969.7 & 12324.3 & 10882.0 \\
\hline \multirow{4}{*}{ Total: [1], [2], [3] } & 2001 & 54488.3 & 38232.7 & 21627.6 & 10981.8 \\
\hline & 2007 & 61440.6 & 68141.5 & 23964.3 & 19348.2 \\
\hline & 2009 & 60887.0 & 66483.5 & 26359.0 & 18551.0 \\
\hline & 2012 & 66869.9 & 62638.0 & 30555.4 & 20075.9 \\
\hline
\end{tabular}

${ }^{*}$ Debt securities division into public and private as in the Report for 2013. In the 2014 Report that division was no longer present.

Source: Own work based on: Global Financial Stability Report, Market Developments and Issues, April 2003, IMF, p. 121, Global Financial Stability Report, Responding to the Financial Crisis and Measuring Systemic Risks, April 2009, IMF, p. 177; Global Financial Stability Report, Durable Financial Stability Getting There from Here. Statistical Appendix, April 2011, IMF, p. 11; Global Financial Stability Report, Statistical Appendix, April 2013, IMF, p. 11, Global Financial Stability Report, Statistical Appendix, April 2014, IMF, p. 153.

The picture of the situation was particularly affected by the size of bank assets, which in the euro area in 2009 was more than twice the size and in 2007 thrice the size of bank assets in the United States. However, in the subsequent years the situation changed. In 2012 the absolute value of stock market capitalisation, debt securities and bank assets total in the United States in was higher than in the euro area. The situation of the euro area was further worsened by the admission of yet more new states. 
Figure 1. Bonds, equities and bank assets (\% of GDP)

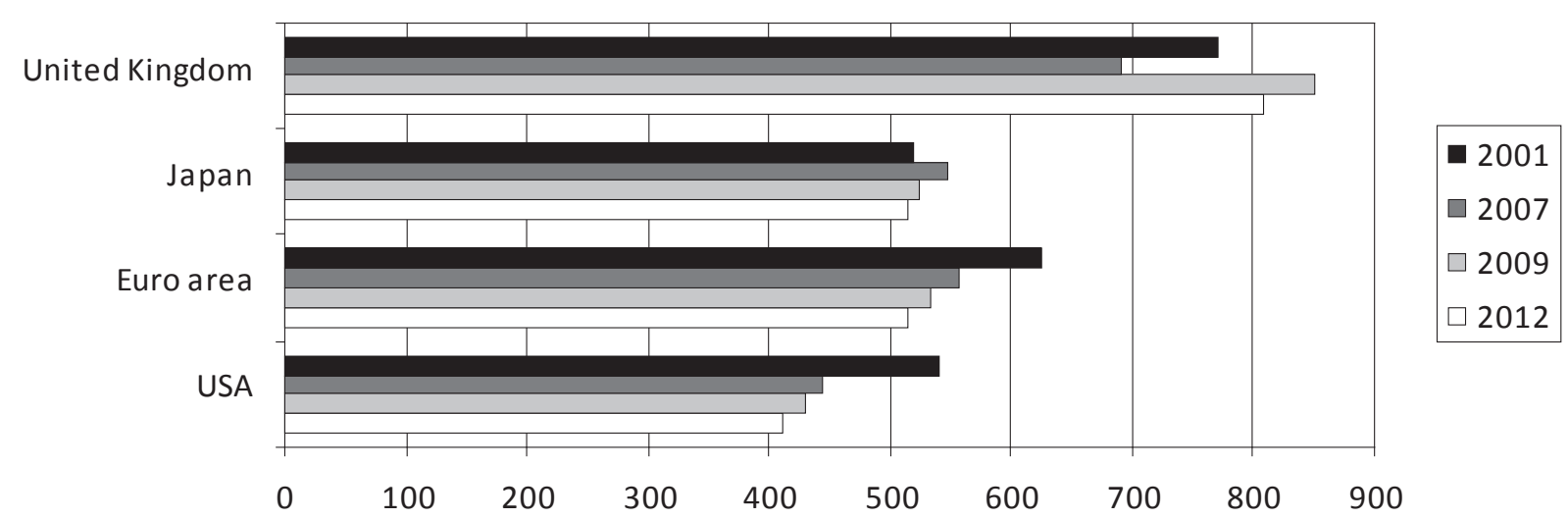

Source: Own work based on Global Financial Stability Report, Market Developments and Issues, April 2003, IMF, p. 121, Global Financial Stability Report, Responding to the Financial Crisis and Measuring Systemic Risks, April 2009, IMF, p. 177; Global Financial Stability Report, Durable Financial Stability Getting There from Here. Statistical Appendix, April 2011, IMF, p. 11; Global Financial Stability Report, Statistical Appendix, April 2013, IMF, p. 11, Global Financial Stability Report, Statistical Appendix, April 2014, IMF, p. 153.

Another obligatory element in the evaluation of the possibility of creating an international currency is the size of bonds and stock market, as it is crucial to the ability of that currency to fulfil the function of a means of accumulation. Taking that element into account, it is necessary to stress that the situation of the EMU worsened particularly in comparison with the United States. In 2012 the value of capitalisation on the stock market in the euro area was just below $35 \%$ of the value of capitalisation of the US stock market, down from 50\% in 2007 and $44 \%$ in 2009. The deterioration of the situation is further illustrated by the fact that in 2001 , when the number of EMU member states was lower, the capitalisation of the euro area stock market was almost $31 \%$ of the value of the US stock market. In 2012 the value of the securities market in the euro area was $82 \%$ of the value of the US securities market, down from $84 \%$ in 2009 . Even though the crisis persists, the US dollar still has larger possibilities to fulfil the function of the currency of accumulation.

The creation of the common currency and the institutionalisation of the monetary union in Europe help to integrate financial markets; however, as time goes by, its level is insufficient, and the national markets of the eurozone remain largely fragmented. One of the fundamental causes of that situation is the fact that each state in the monetary union has its own legal system, for example corporate bond markets with different accounting standards, corporate tax rates, or shareholders' rights and acquisition laws. All those differences influence the prices of the corporate bonds. The stock market is yet another example that still shows the tendency to stick to national stock markets, which is caused by the barriers set by different member states regulations on accounting standards, taxation and corporate governance. Additionally, 
bond markets in the eurozone member states substantially differ in size, the differences having been further augmented by the recent economic crisis. The differences in the size of bond markets are directly caused by the differences and disparities of the potential and scale of the economies between the eurozone member states as well as by the state of their economies, including the state of each public sector.

The international position of a currency is determined not only by structural factors, but also by the state or monetary union economic policy. A stable monetary and fiscal policy is a factor that positively influences the position of a currency. The recent economic crisis further increased the differences and disparities between principal issuers of international currencies and inside the euro area. To verify the efficiency and stability of monetary policy one can use the CPI, albeit with some reservations. According to Figure 2, the CPI indicator in 2001 and between 2007 and 2013 fluctuated slightly but not in a degree that could put in doubt the efficiency of the European Central Bank's policy regarding the direct inflation target. Additionally, the euro area did not experience deflation, although some threat of deflation was observed in the first phase of the economic crisis. However, one needs to bear in mind that - in the context of non-standard measures used by the ECB in the monetary policy directed at limiting the crisis - a threat of high inflation in the future exists. Depending on the scale and intensity of potential inflation in other regions, this may influence the perspectives of making the euro an international currency.

Figure 2. Annual CPI for selected countries (\%)

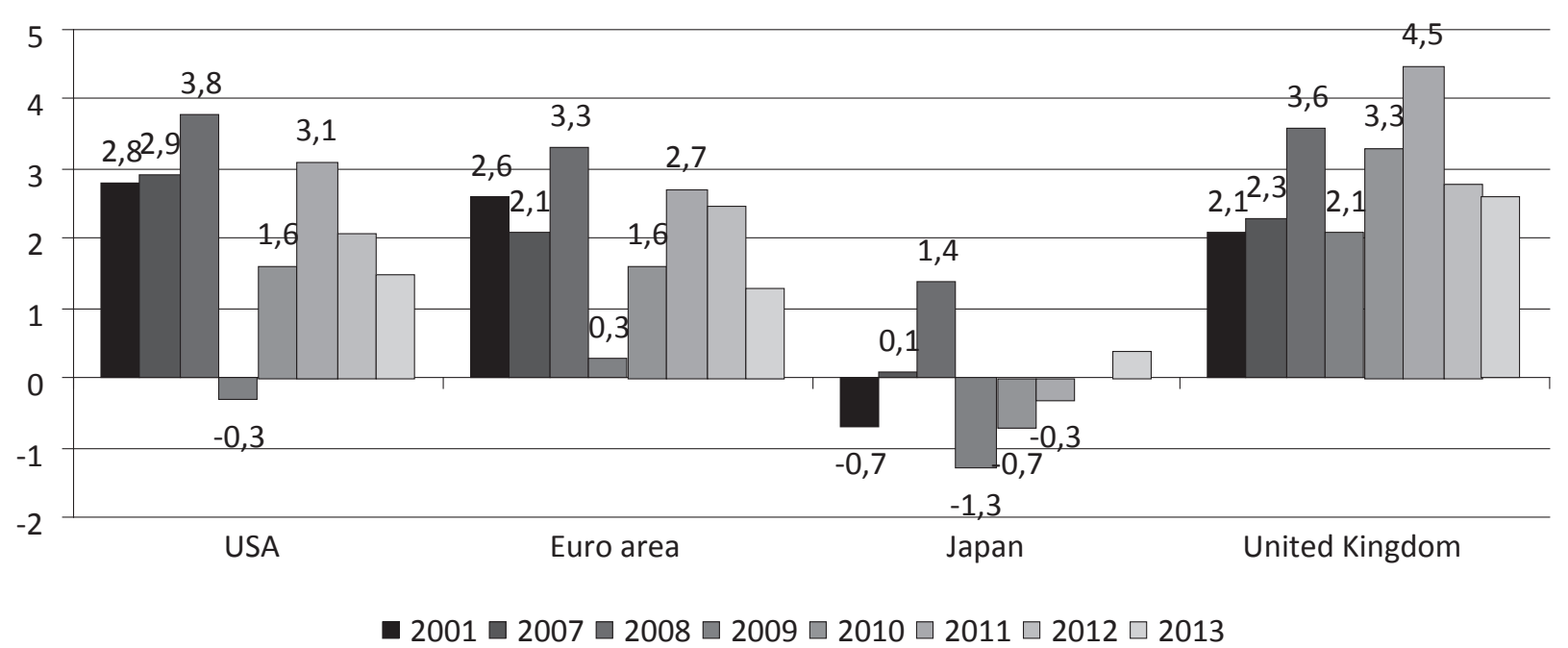

Source: Own work based on World Economic Outlook, Recessions and Recoveries, April 2002, IMF, p. 169, World Economic Outlook. Hopes, Realities, Risks, April 2013, IMF, p. 157, World Economic Outlook. Recovery Strengthens, Remains Uneven, April 2014, IMF, p. 188. 
Stable fiscal policy is another factor that is taken into account when evaluating whether a currency can fulfil an international function. The situation in that sphere has also worsened globally in recent years. According to IMF, in 2013 the general government gross debt in Japan equalled 243.2\% of GDP, in the USA - 104.5\% and in the euro area - above $95 \%$, see Figure 3. It needs to be stressed that public debt has never gone below the reference level since the monetary union in Europe was created. At all times, the public debt of all eurozone member states was above $60 \%$ of GDP and even above $80 \%$ in the recent years. Additionally, one needs to remember that public debt is internally differentiated. The average debt of the euro area is particularly influenced by several states, particularly Greece - $156.9 \%$ of GDP in 2012, Italy (127\%), Portugal (123.6\%), and Ireland (117.6\%). However, the euro area's leading economies also didn't satisfy the public debt criteria: the public debt of Germany reached $81.9 \%$ of GDP and of France - 90.2\%. Among EMU member states Estonia, Luxembourg, Finland, Slovakia and Slovenia had the best public debt GDP ratio: they were the only countries whose public debt was below $60 \%$ of GDP in 2012.

\section{Figure 3. Gross debt, percent of GDP}

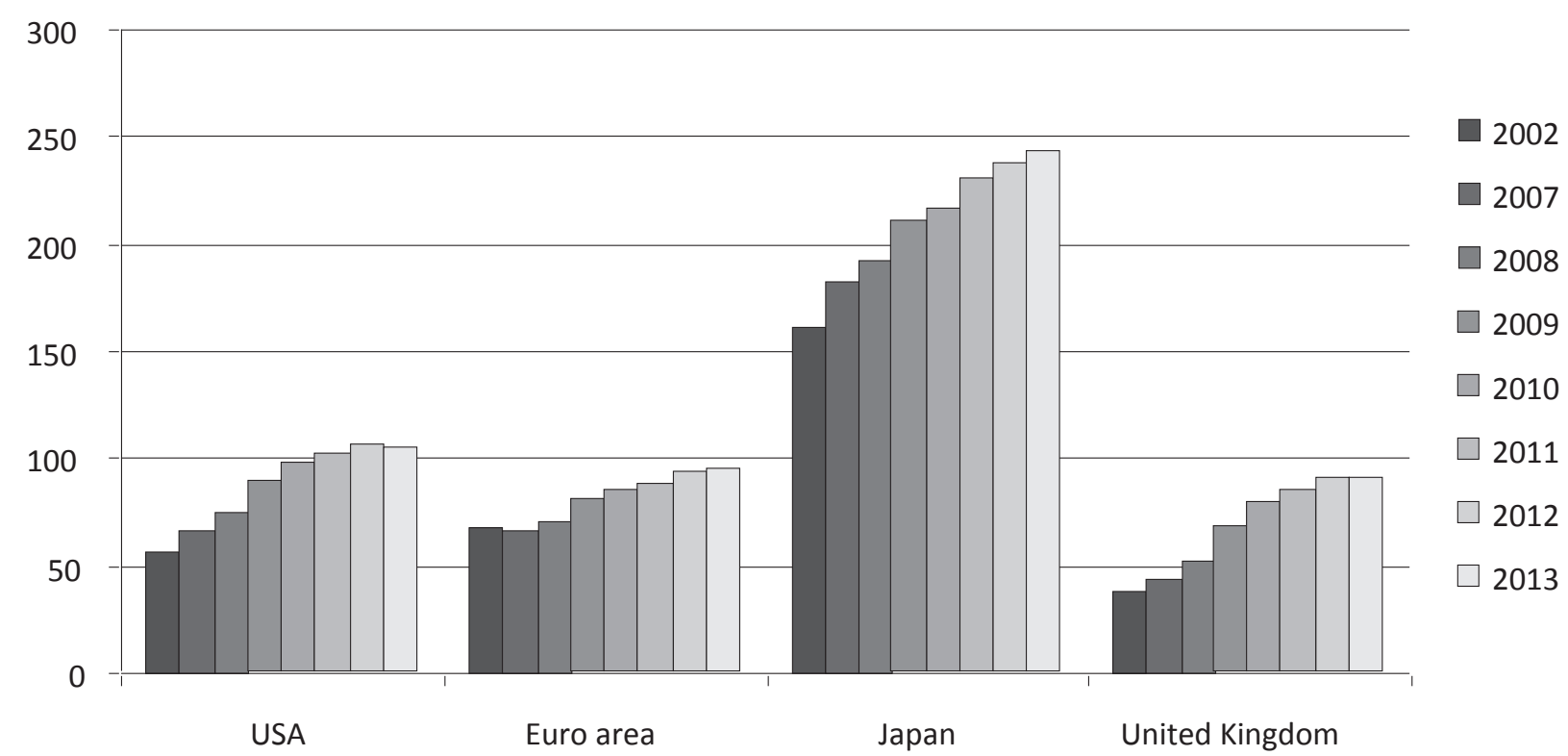

Source: Own work based on World Economic Outlook. Housing and the Business Cycle, April 2008, IMF, s. 155, World Economic Outlook. Hopes, Realities, Risks, April 2013, IMF, p. 161, World Economic Outlook. Recovery Strengthens, Remains Uneven, April 2014, IMF, p. 192.

The relatively good situation in the euro area regarding public debt levels in comparison with Japan and the USA is the result of inter alia adding new member states to statistics. For example, after experiencing the economic crisis that was reflected in the public finances, Estonia as a new member state rapidly returned to budget 
surplus and improved the public debt situation. The situation was also influenced by the strategy of handling the crisis (based on austerity measures) that is different than in the USA. The latest experiences of the European Union and the eurozone member states have showed that it is very difficult to retain cohesion of the monetary union and the position of regional currency in the international arena without a common fiscal policy. The fact that the unemployment level in the euro area is higher than in the USA and that economic growth is lower (see Table 3) just proves the point. For example, in 2011 the unemployment rate in the United States was 9\% and in the euro area 10.1\%, but the IMF estimates that in 2015 the unemployment rate in the USA will be just $6.2 \%$ while in the euro area $-11.6 \%$.

Table 3. Real economic growth (\%)

\begin{tabular}{|c|c|c|c|c|c|c|c|c|c|}
\hline & 2000 & 2001 & 2010 & 2011 & 2012 & 2013 & $2014^{\star}$ & $2015^{\star}$ & $2019^{\star}$ \\
\hline USA & 4.1 & 1.2 & 2.5 & 1.8 & 2.8 & 1.9 & 2.8 & 3.0 & 2.2 \\
\hline Euro area & 3.4 & 1.5 & 2.0 & $1, .6$ & -0.7 & -0.5 & 1.2 & 1.5 & 1.5 \\
\hline Japan & 2.2 & -0.4 & 4.7 & -0.5 & 1.4 & 1.5 & 1.4 & 1.0 & 1.1 \\
\hline United Kingdom & 3.0 & 2.2 & 1.7 & 1.1 & 0.3 & 1.8 & 2.9 & 2.5 & 2.4 \\
\hline
\end{tabular}

${ }^{*}$ Forecasts

Source: Own work based on World Economic Outlook, Recessions and Recoveries, April 2002, IMF, p. 158, World Economic Outlook. Hopes, Realities, Risks, April 2013, IMF, p. 149, World Economic Outlook. Recovery Strengthens, Remains Uneven, April 2014, IMF, p. 181.

The military-political factor is one of the obstacles to replacing the dollar by the euro - as suggested by the authors of the "Euro's international role 3" (Międzynarodowa rola euro III) report - as the international currency. What gave rise to this obstacle is the lack of unified political leadership, sufficient military power and real coordination of foreign policy of the eurozone member states. The present Ukrainian crisis seems to confirm this thesis. Whereas in a good economic situation and in a stable regional and global political situation, these differences in opinion didn't seem to matter, they do during crises or international conflicts. National interests and conflicts about political and economic spheres of influence affect the effectiveness of the common EU and eurozone policy. Elimination of these obstacles is possible only through more integration: extending the present monetary union to economic union, and subsequently political union. However, the dominant positions on the issue of further integration in the member states make a political

\footnotetext{
6 World Economic Outlook. Growth Resuming, Dangers Remain, April 2012, IMF, p. 58. IMF, World Economic Outlook. Recovery Strengthens, Remains Uneven, April 2014, IMF, p. 52.
} 
union - a confederation - highly unlikely, not only in the near future. Moreover, suggestions for limiting or even rolling back the integration to the point of allowing member states to leave the Union are being voiced more often than ever. This is yet another factor that negatively influences the trust in the euro and weakens its position on the international market.

Taking into account all of the above, one needs to agree that the Economic and Monetary Union with all its weaknesses meets the fundamental criteria and conditions for issuing a currency that fulfils the function of international currency both in official and private spheres. What is the international situation of the euro, then, particularly after the last financial market, real economy and public debt crises? It seems that the euro carries out the function of international currency both in the official and private spheres, and currently the situation is stable due to the particular position of the new international currency in the regional setting. In the international context, the euro enables to measure value both in official and private contexts. In the official context it is the reference currency in exchange rate regimes in about 40 states - see Table 4 .

Table 4. Countries and Territories with Exchange Rate Regimes Linked to the Euro

\begin{tabular}{|c|c|c|}
\hline Region & Exchange rate regimes & Countries \\
\hline \multirow[t]{4}{*}{ EU (non-euro area) } & ERM II & Denmark, Latvia, Lithuania \\
\hline & Euro-based currency boards & Bulgaria \\
\hline & Managed floating regime with the euro as & Czech Republic, Romania \\
\hline & $\begin{array}{l}\text { reference currency and an inflation target } \\
\text { Pro memoria: Free-floating regime with an } \\
\text { inflation target }\end{array}$ & $\begin{array}{l}\text { Hungary, Poland, Sweden, } \\
\text { United Kingdom }\end{array}$ \\
\hline \multirow[t]{3}{*}{$\begin{array}{l}\text { EU acceding, candidate and potential } \\
\text { candidate countries }\end{array}$} & $\begin{array}{l}\text { Unilateral euroisation (no separate legal } \\
\text { tender) }\end{array}$ & Kosovo, Montenegro \\
\hline & $\begin{array}{l}\text { Euro-based currency boards } \\
\text { Stabilized arrangement with euro as a }\end{array}$ & $\begin{array}{l}\text { Bosnia and Herzegovina } \\
\text { Croatia, Former Yugoslav Republic of } \\
\text { Macedonia }\end{array}$ \\
\hline & $\begin{array}{l}\text { Pro memoria: Free-floating regime with } \\
\text { an inflation target }\end{array}$ & Albania, Iceland, Serbia, Turkey \\
\hline \multirow[t]{5}{*}{ Others } & Euroisation & $\begin{array}{l}\text { European microstates, some French } \\
\text { overseas collectivities }\end{array}$ \\
\hline & Pegs based on the euro & $\begin{array}{l}\text { CFA franc zone, CFP franc zone, Cape } \\
\text { Verde, Comoros, São Tomé e Príncipe }\end{array}$ \\
\hline & $\begin{array}{l}\text { Other arrangements using the euro as a } \\
\text { reference currency }\end{array}$ & Switzerland \\
\hline & Crawling peg involving the euro & Botswana \\
\hline & $\begin{array}{l}\text { Pegs and managed floats based on the } \\
\text { SDR and other currency baskets involving } \\
\text { the euro (share of the euro) }\end{array}$ & $\begin{array}{l}\text { Algeria, Belarus, Fiji, Iran, Kuwait, Lybia, } \\
\text { Morocco ( } 80 \%) \text {, Russian Federation } \\
\text { (45\%), Samoa, Singapore, Syria, Tunisia, } \\
\text { Vanuatu }\end{array}$ \\
\hline
\end{tabular}

Source: The International Role of the Euro, European Central Bank, July 2013, p. 67.

Using the euro as the reference currency is determined by geographical and institutional factors; it is used particularly by the states neighbouring with the EU, by the 
states that have signed special institutional agreements with the EU, and by its member states. States whose monetary systems are based on the euro include EU member states that are not euro area member states but that participate in the ERM II, such as Bulgaria (Euro-based currency board) and Romania (managed floating regime with the euro as its reference currency). The second group includes EU candidate states or potential EU candidate states such as Kosovo or Montenegro (which have already unilaterally adopted the euro), Bosnia and Herzegovina (euro-based currency board), and Croatia and the Former Yugoslav Republic of Macedonia (stabilised arrangement with the euro as a reference currency). Additionally, it needs to be stressed that the revision of the SDR (Special Drawing Rights) basket in November 2010 caused an increase in the euro share from $34 \%$ in 2005 to $37.4 \%$ in $2010^{7}$.

The US dollar is still often used as the anchor currency in Latin America and in Asia. Some countries have officially or unofficially dollarised their currencies. Some examples of countries that have officially dollarised their currencies include Panama, which in 1904 adopted the US dollar as its official currency alongside balboa, and Ecuador and Salvador, which adopted it in the 21st century. Guatemala and Nicaragua are currently considering such a step.

The stable regional position of the euro as measurement of wealth can be also observed in the private sphere, where the euro is used for invoicing. While in the global dimension, the euro is rarely, or at least less frequently than the US dollar, used for clearing transactions and measuring value in international agreements, in the regional dimension it is used much more often, as most trade within the European Union and the states linked to its structures is invoiced in euro.

The key function of the international currency is storing of value. In the official sphere, storing of value usually means considering a currency as suitable for holding reserves. This can be easily measured as a share of a currency in the official currency reserves. Many factors influence the central bank's choice of reserve currency, such as the exchange mechanism, the anchor currency, foreign trade, the invoicing currency, the debt currency and the strategy of risk diversification. Important determinants of monetary structure of reserves include size and liquidity of securities market denominated in a currency as well as exchange rate changes ${ }^{8}$. At the end of 2012, the value of global currency reserves reached 10.9 trillion US dollars. Between 2002 and 2012 the euro's share (constant exchange rate) in reserves of central banks that disclosed their reserves dropped from $27.3 \%$ to $23.9 \%$. However, the euro took the largest share of reserves (25.5\%) in 2009, and since then each year that share has been

\footnotetext{
7 Yet another revision of the SDR basket is scheduled for 2015.

${ }^{8}$ Międzynarodowa rola euro III..., op.cit., p. 14.
} 
declining. At the same time, the US dollar's share remained stable at around 62\%, while the Japanese yen dropped from $6.2 \%$ to $3.9 \%$ and the share of other currencies rose from $4.5 \%$ to $6.1 \%^{9}$ - see Figure 4 . In comparison to 2010 , the euro's share of central banks' reserves (constant exchange rate) of the banks disclosing their reserves dropped in 2012 by 1.5 percentage point, while the US dollar dropped by just 0.3 percentage point, the share of the Japanese yen remind stable, and other currencies dropped by 2.4 percentage point.

Figure 4. Currency shares in foreign exchange reserves with disclosed currency composition (at constant exchange rates - \%)

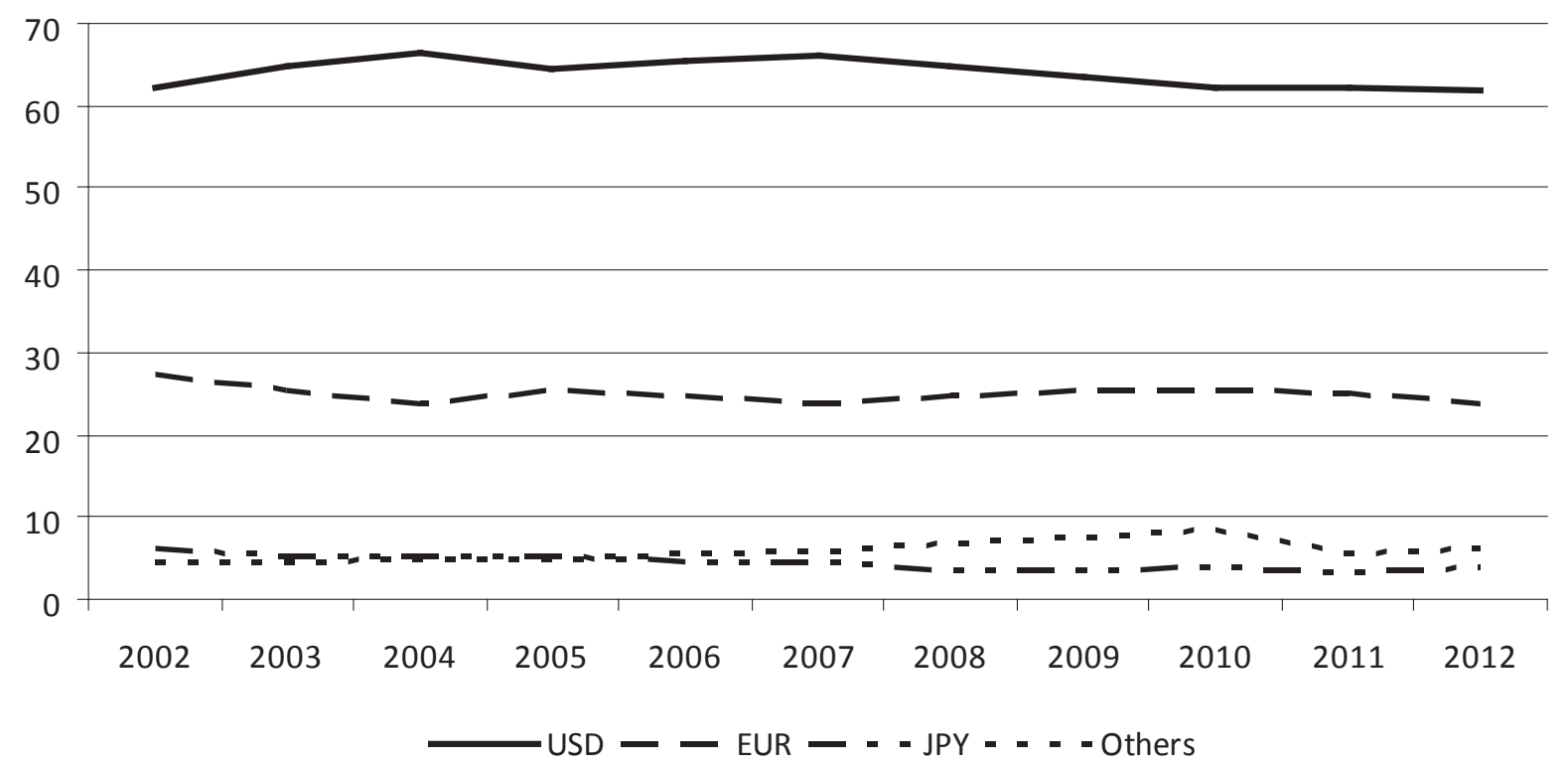

Source: Own work based on The International Role of the Euro, July 2011, European Central Bank 2012, p. 54, The International Role of the Euro, July 2013, European Central Bank 2013, p. 64.

In the private sphere, the function of storing of value is performed through the intervention currency, for instance when issuing securities in a currency different that the currency of the state where the debtor resides. At the end of 2012 the value of debt securities (current exchange rates, narrow measure) was $\$ 11.8$ trillion, of which $25.5 \%$ ( $\$ 3.0$ trillion) was denominated in euro, $52.4 \%$ ( $\$ 6.2$ trillion) in US dollars and $4.9 \%$ ( $\$ 581$ billion) in Japanese yen - see Figure 5. The share of USD was the highest since 2000, which suggested that private entities intervene in that currency disregarding the crisis. Already in the 2000s before the economic crisis, one could observe a decline in the share of the dollar in issued securities (current exchange rates) and a rise in euro denominated securities, but that changed after the crisis

9 The International Role of the Euro, July 2011, European Central Bank, 2012, p. 54 and The International Role of the Euro, July 2013, European Central Bank, 2013, p. 64. 
began. After 2008, one has been able to observe "the scissors open" and a decline in the share of securities denominated in the euro (current exchange rates) and the rise of the dollar share. Although both USA and the eurozone member states suffered the consequences of the crisis, issuers of debt securities prefer the US dollar to the euro, which was most probably caused by the uncertainty regarding the future and durability of the EMU. Notwithstanding these uncertainties, the euro has kept its position as the second intervention currency at the international debt securities market, while the difference between the euro and the group of the so-called other currencies has diminished.

Figure 5. Outstanding international debt securities, narrow measure. Percentages of outstanding amounts (at current exchange rates, end of period)

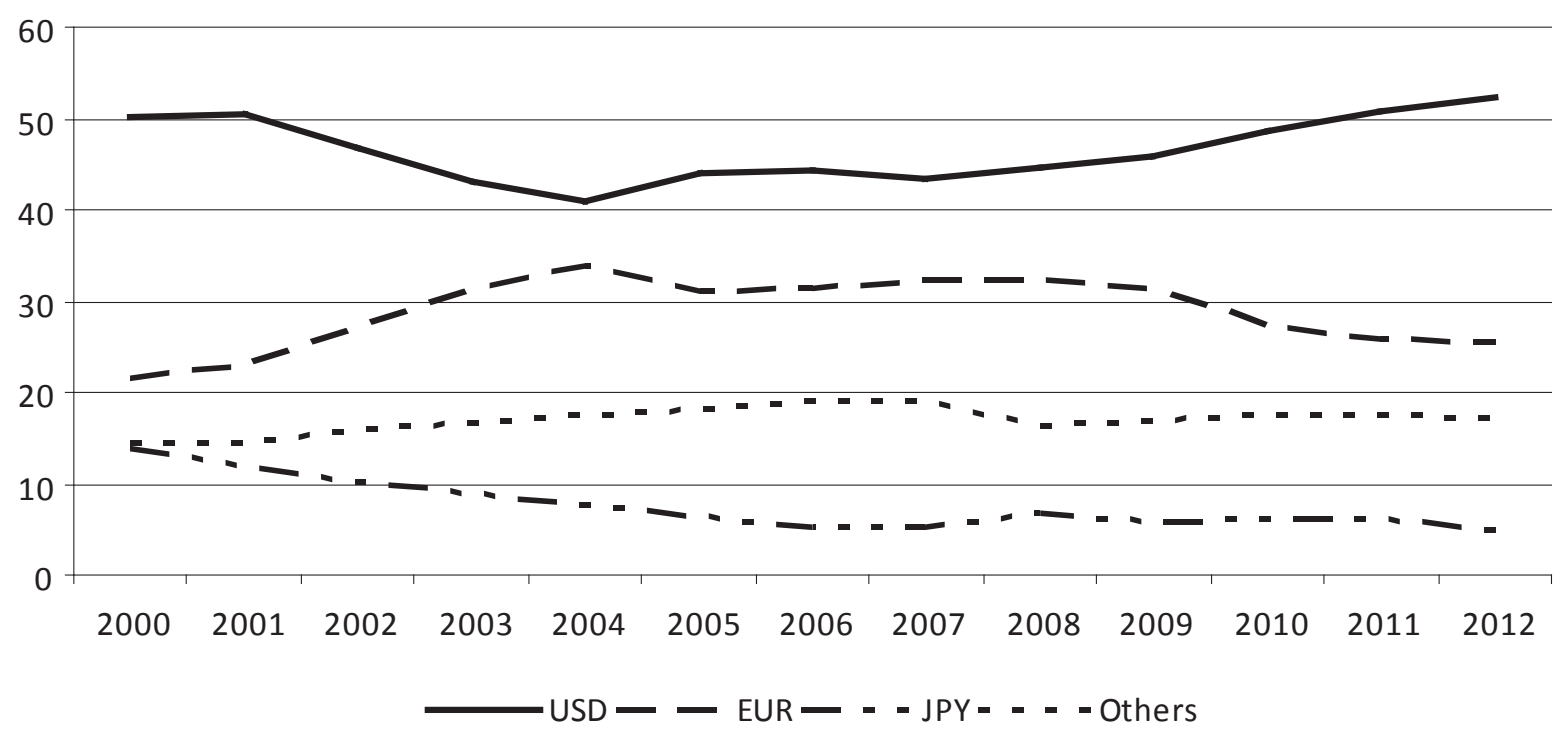

Source: Own work based on The International Role of the Euro, July 2011, European Central Bank, 2012, p. 58, The International Role of the Euro, July 2013, European Central Bank, 2013, p. 68.

Financial institutions are the largest issuer of securities denominated in euros, and in comparison to issuers of securities denominated in US dollars they are much more concentrated geographically. In 2010, most of the new securities denominated in the euro on the international securities market were issued by financial institutions in the United Kingdom and Scandinavia, particularly Norway, Sweden and Denmark. Interestingly, according to the data in Table 5, in 2010 among non-eurozone member states Poland was one of the largest issuers of bonds denominated in euro: it was ranked sixth, and the value of securities issued was 5.25 billion euro. Among non-US based issuers of securities denominated in US dollars such geographical and organisational concentration cannot be observed. They include financial 
institutions and international organisations from various regions such as Europe, Australia or Canada.

Table 5. Largest issuers of euro-denominated securities from outside the euro area and largest issuers of USD-denominated securities from outside USD in 2010

\begin{tabular}{|c|c|c|c|c|}
\hline No. & $\begin{array}{l}\text { Issuers of euro-denominated securities } \\
\text { from outside the euro area }\end{array}$ & $\begin{array}{c}\text { Value of } \\
\text { securities } \\
\text { (million EUR) }\end{array}$ & $\begin{array}{l}\text { Issuers of USD-denominated } \\
\text { securities from outside USA }\end{array}$ & $\begin{array}{c}\text { Value of } \\
\text { securities } \\
\text { (million EUR) }\end{array}$ \\
\hline 1 & Lloyds TSB Bank plc & 11534 & KfW Bankengruppe - LfW & 27422 \\
\hline 2 & Royal Bank of Scotland plc & 10805 & European Investment Bank - EIB & 22357 \\
\hline 3 & Barclays Bank plc & 9872 & $\begin{array}{c}\text { International Bank for Reconstruction } \\
\text { \& Development - World Bank }\end{array}$ & 15353 \\
\hline 4 & Nordea Bank AB & 7514 & Westpac Banking Corp & 10420 \\
\hline 5 & DnB NOR Boligkreditt AS & 5796 & Bank of Nova Scotia & 9344 \\
\hline 6 & Republic of Poland & 5250 & Rabobank Nederland & 8255 \\
\hline 7 & Abbey National Treasury Services plc & 5106 & Province of Ontario & 8022 \\
\hline 8 & UBS AG (London) & 5052 & National Australia Bank Ltd & 7656 \\
\hline 9 & Credit Agricole SA (London) & 4836 & Barclays Bank plc & 7399 \\
\hline 10 & HSBC Bank plc & 4707 & Royal Bank of Canada & 7036 \\
\hline 11 & Swedbank Mortgage AB & 4590 & Royal Bank of Scotland plc & 6574 \\
\hline 12 & Credit Suisse (London) & 4201 & NRW Bank & 6328 \\
\hline 13 & Bank of America Corp & 3699 & Asian Development Bank & 6202 \\
\hline 14 & Danske Bank A/S & 3400 & $\begin{array}{c}\text { Inter-American Development Bank - } \\
\text { IADB }\end{array}$ & 6013 \\
\hline 15 & Nationwide Building Society & 3292 & $\begin{array}{c}\text { Australia \& New Zealand Group Ltd - } \\
\text { ANZ }\end{array}$ & 5461 \\
\hline 16 & National Australia Bank Ltd & 3275 & $\begin{array}{c}\text { Bank Nederlandse Gemeenten NV - } \\
\text { BNG }\end{array}$ & 5411 \\
\hline 17 & Swedish Covered Bond Corp & 3040 & ING Bank NV & 5401 \\
\hline 18 & Credit Suisse (Guernsey) Ltd & 3000 & Lloyds TSB Bank plc & 5374 \\
\hline 19 & Skandinaviska Enskida Banken AB-SEB & 2921 & Shell International Finance BV & 5306 \\
\hline 20 & BES Finance Ltd & 2800 & $\begin{array}{l}\text { Caisse d'Amortissement de la Dette } \\
\text { Sociale - CADES }\end{array}$ & 5263 \\
\hline
\end{tabular}

Source: The International Role of the Euro, July 2011, European Central Bank 2011, p. 23 and Międzynarodowa rola euro III. Departament Integracji ze Strefą Euro, Narodowy Bank Polski, Warszawa 2011, p. 24.

In 2012, the situation did not change substantially: most of the issuers of the euro-denominated securities from outside the euro area were European financial institutions. Among the issuers of the dollar-denominated securities from outside of the USA one can observe wider geographical dispersion - the issuers include organisations from North and Latin America as well as from Europe and other continents. 
Table 6. Largest issuers of euro-denominated securities from outside the euro area and the largest issuers of USD-denominated securities from outside USD in 2012

\begin{tabular}{|c|c|c|c|c|}
\hline No & $\begin{array}{c}\text { Issuers of euro-denominated securities } \\
\text { from outside euro area }\end{array}$ & $\begin{array}{c}\text { Value of } \\
\text { securities } \\
\text { (million EUR) }\end{array}$ & $\begin{array}{c}\text { Issuers of USD-denominated } \\
\text { securities from outside USA }\end{array}$ & $\begin{array}{c}\text { Value of securities } \\
\text { (million EUR) }\end{array}$ \\
\hline 1 & Abbey National Treasury Service plc & 11201 & Kreditanstalt fur Wiederaufbau & 26366 \\
\hline 2 & Lloyds TSB Bank plc & 11055 & European Investment Bank - ElB & 21778 \\
\hline 3 & Barclays Bank plc & 8461 & Republic of the Philippines & 16769 \\
\hline 4 & Danske Bank A/S & 8031 & Bank of Nova Scotia & 14939 \\
\hline 5 & DnB Boligkreditt AS & 6880 & Barclays Bank plc & 13637 \\
\hline 6 & Nordea Bank AB & 5628 & London Branch CORP & 11990 \\
\hline 7 & Poland Republic of (Government) & 5500 & $\begin{array}{c}\text { Caisse D' amortissement de la Dette } \\
\text { Sociale }\end{array}$ & 10520 \\
\hline 8 & Swedbank AB & 4875 & Kingdom of the Netherlands & 10423 \\
\hline 9 & Commonwealth Bank of Australia & 4850 & Kommunalbanken AS & 10313 \\
\hline 10 & Svenska Handelsbanken AB & 4806 & $\begin{array}{c}\text { International Bank for Reconstruction } \\
\text { \& Development - World Bank }\end{array}$ & 10266 \\
\hline 11 & Credit Agricole SA London Branch & 4057 & Dutch State Treasury Agency & 10000 \\
\hline 12 & BHP Billiton Finance Ltd & 4000 & ING Bank N.V. & 9915 \\
\hline 13 & Nationwide Building Society & 3663 & $\begin{array}{c}\text { Australia \& New Zealand Banking } \\
\text { Group Ltd }\end{array}$ & 9323 \\
\hline 14 & Banco Espirito Santo SA & 3658 & Nv Bank Nederlandese Gemeenten & BNG \\
\hline 15 & UBS AG (London Branch) & 3638 & Ukraine (Government) & 8710 \\
\hline 16 & National Australia Bank Ltd & 3565 & $\begin{array}{c}\text { Cooperative Centrale Raiffeisen- } \\
\text {-Boerenleenbank B.A. }\end{array}$ & 8549 \\
\hline 17 & Ministry of Finance of the Czech Republic & 3500 & Volkswagen International Finance NV & 8524 \\
\hline 18 & Standard Chartered PLC & 3500 & Commonwealth Bank of Australia & 8098 \\
\hline 19 & DLR Kredit A/S & 3319 & SB Capital SA & 7731 \\
\hline 20 & Holmes Master Issuer PLC & 3050 & Lyondellbasel Industries NV & 7693 \\
\hline
\end{tabular}

Source: The International Role of the Euro, July 2013, European Central Bank 2013, p. 75.

The analysis of the euro's function of storing value in the private sphere can be supplemented by a subdivision of securities issuance into euro area residents and non-euro area residents issuance. What needs to be stressed is the fact that a currency, in this case the euro, can be used on the international securities market when an instrument denominated in that currency is issued by a resident of a state that is not an issuer of that currency (as is the case with the euro from outside the euro area), held by a non-resident, or both issued and held by non-resident. At the end of $2012,87 \%$ of euro-denominated securities (total value $€ 14.884$ billion) were issued by residents while non-residents issued just $13 \%$ of securities (total value $€ 2.3$ billion). This data supports the conclusions drawn from the analysis of the main issuers 
of securities on the international markets. What is more, comparing the 2012 data with the data at the end of June 2010, one can observe a small increase in the share (and value) of securities issued by residents: at the end of June 2010 the residents' share was $86 \%$ (value $€ 13.897$ billion). Euro area residents at the end of June 2012 held $78 \%$ of securities denominated in the euro (value $€ 13.406$ billion), which is at the same level as in the past, although the value of the securities held slightly rose. Between June 2010 and June 2012, the share of securities issued by euro area residents but held by non-euro area residents declined from $18 \%$ to $17 \%{ }^{10}$.

The share claimed by a currency in the international loans and deposits market is important in fulfilling its international function as an investment currency. The euro's position on the international area in the last years has been stable, similar to that of 'other currencies' but much weaker than that of the US dollar. Therefore, one can speculate that the expectations of euro creators were much greater. Figure 6 shows that at the end of 2012 the euro's share in the currency structure (current exchange rates) of all cross-border loans was $20.3 \%$, compared to $56.5 \%$ of USD and $2.8 \%$ of Japanese yen.

Figure 6. International loans by currency 2000-2012 (at current exchange rates, end of period - \%)

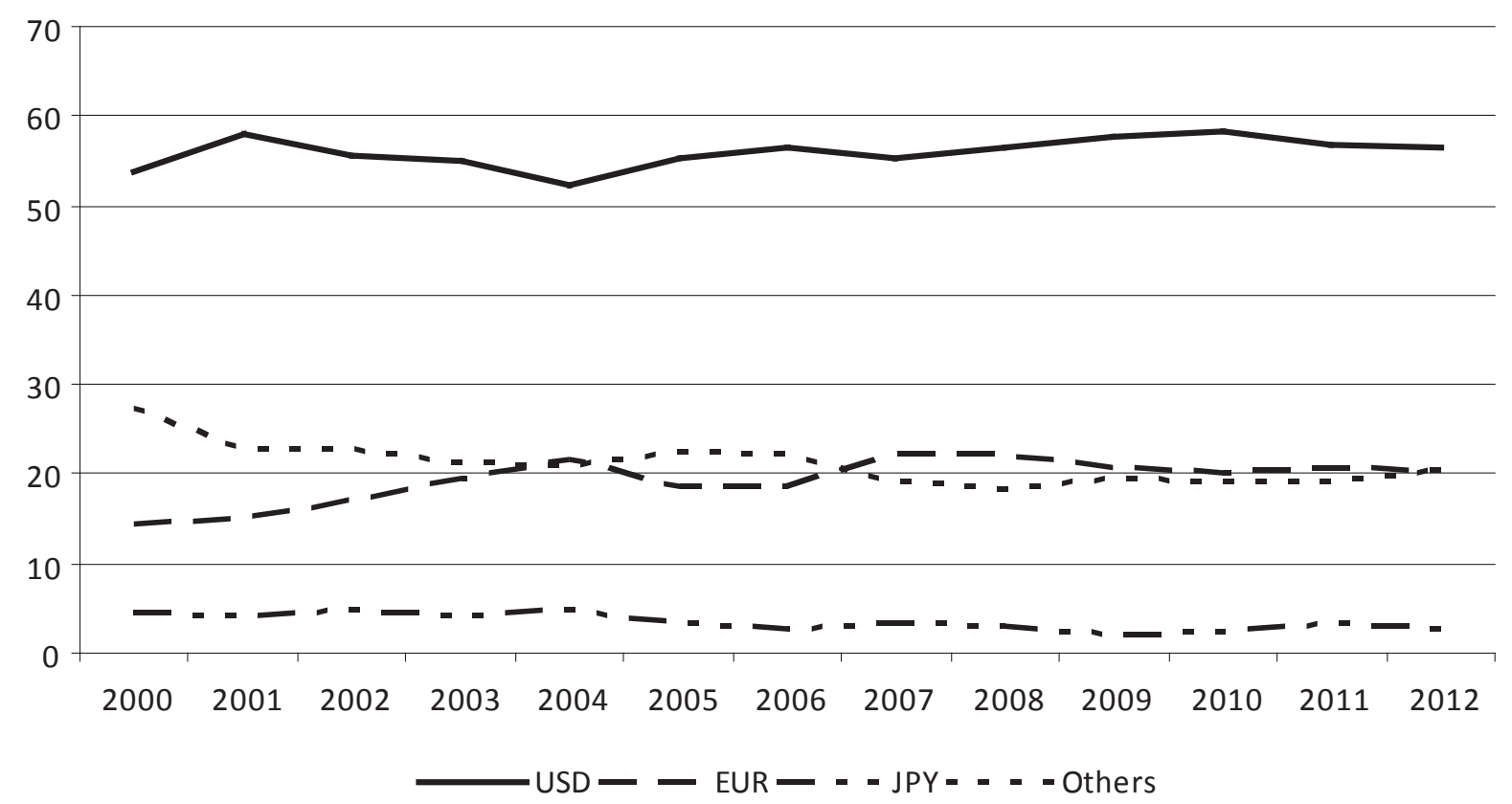

Source: Own work based on The International Role of the Euro, July 2012, European Central Bank 2012, p. 69, The International Role of the Euro, July 2013, European Central Bank 2013, p. 76.

10 The International Role of the Euro, July 2013..., op.cit., p. 73 and Międzynarodowa rola euro III..., op.cit., p. 25. 
Of course, the euro is also an important international deposits currency, although the dominance of the US dollar is even in this case greater than in case of loans. At the end of 2012 the share claimed by each currency of cross-border deposits was as follows: euro $19 \%$, US dollar $60.1 \%$, Japanese yen $1.8 \%$ - see Figure 7 . What needs to be stressed is the fact that the euro slowly loses its position to other currencies.

Figure 7. International deposits by currency 2000-2012 (at current exchange rates, end of period - \%)

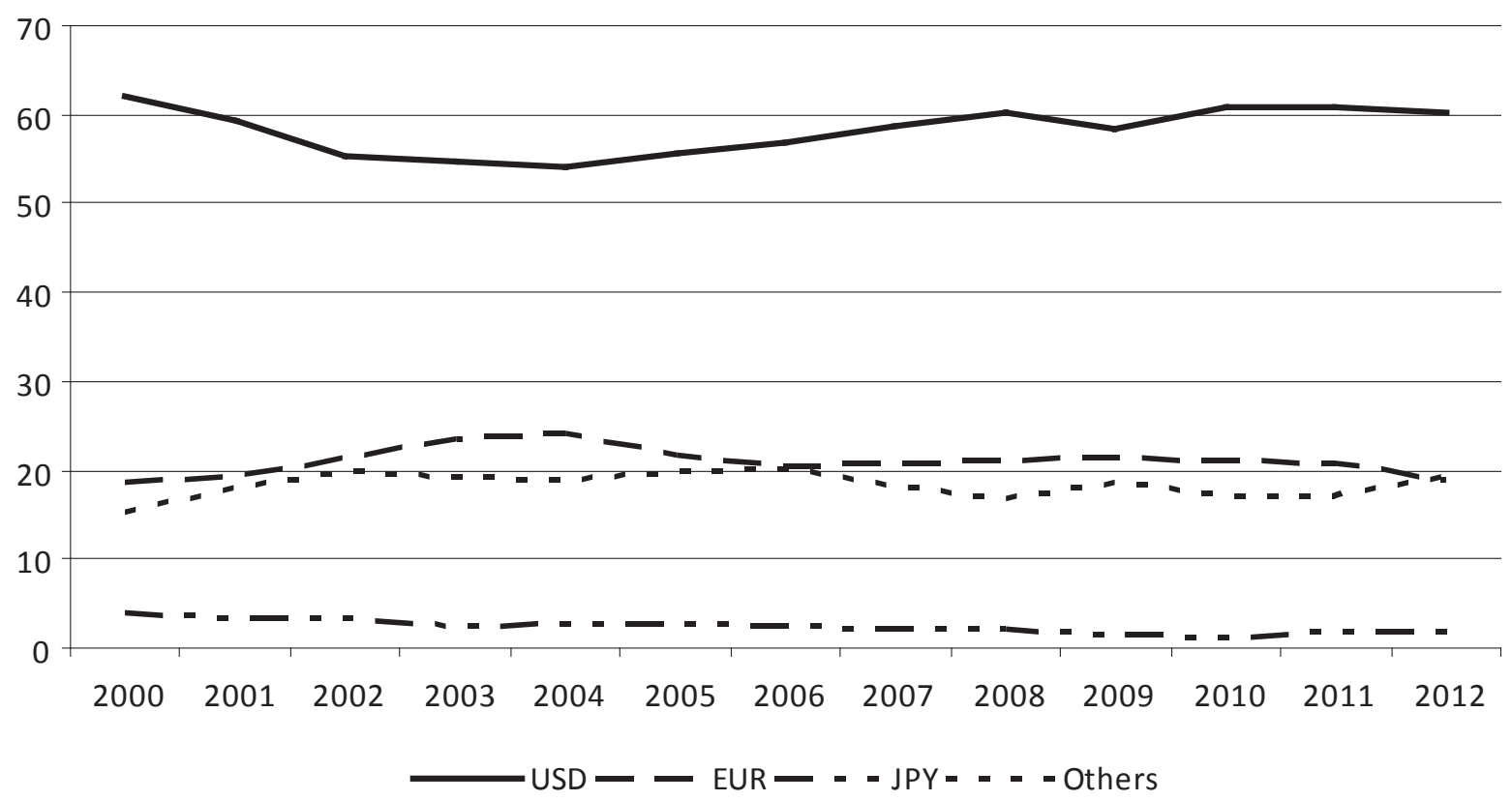

Source: Own work based on The International Role of the Euro, July 2012, European Central Bank 2012, p. 69, The International Role of the Euro, July 2013, European Central Bank 2013, p. 77.

The function of a currency in the international area in the official sphere is also the one of intervention currency. In the afermath of the 2007 crisis on the financial markets, the principal central banks not only began using non-standard financial market instruments but also became active in the currency market and began influencing currency exchange rates on a much larger scale. As a result of the undertaken interventions, the share of the euro in the reserves of developed economies declined from $25.8 \%$ in 2010 to $23.9 \%$ in 2012 (fixed exchange rates). Similar changes but on a smaller scale were observed in case of the US dollar, which declined from $62.1 \%$ in 2010 to $61.9 \%$ in 2012 . The share claimed by the Japanese yen rose from $3.5 \%$ to $3.9 \%$, and the share of other currencies rose from $4.5 \%$ to $6.1 \%{ }^{11}$.

11 The International role of the Euro, July 2013..., op.cit., p. 64. 
The international position of a currency is directly determined by the scale and manner of how it performs the classic currency functions in the international context. As seems clear from the analysis in this paper, the creation of the Economic and Monetary Union and the introduction of a new currency (euro) - even though the decision was strictly political - was well-received by entities of contemporary international economy, including its main participants and the players on the international currency market. The reason for such a reception was the potential of the economies in the euro area, and also structural conditions and expectations for he creation of an international currency that was to constitute a real alternative to the US dollar. The possibility of diversification in the investment and reserve spheres as well as in reference, intervention, transfer and invoicing spheres was considered a step in the right direction to limit the domination of the US dollar on the market. The first years after the creation of the new European currency pointed to the existence of a permanent trend of strengthening of the position of the euro on the international area, both in the official and private spheres vis-à-vis not only the Japanese yen and the group of the so-called 'other currencies' but especially the US dollar. It was believed that - with the favourable conditions inside the euro area and its closest environment, and the increasing economic problems of the USA - the euro would have a chance to become in the mid-term perspective a globally important currency and would pose a threat to the US dollar.

The latest financial and economic crisis revised the opinions on the importance of the euro in the contemporary economy. Moreover, it seems justified to stress that the change of opinions was not only caused by the latest economic crisis that began in the USA, but also by the irregularities and methodological mistakes made when creating the EMU. The lack of common fiscal policy may pose a serious threat to the cohesion of the euro area and the durability of the EMU. Therefore, claims that the latest financial and economic crisis only speeded the unravelling of the internal problems of the euro area and brought to light the threats that influence the factors important for the international position of a currency are justified.

Notwithstanding the increasing problems in the fiscal sphere and the real economy, particularly in the job market, one may agree that the latest economic crisis did not change the bipolar character of the international monetary system still based on the US dollar and the euro. However, it needs to be stressed that the euro remains more of a regional than a global currency. What is more, one can speculate that thanks to the so-called network effects caused by the regional interconnectedness of economies and currencies with the euro, and due to the lack of alternative to the 
euro, it will remain the second international currency and regional currency at least in the short-term and possibly in the mid-term perspective.

\section{The influence of economic crisis on the international position of the euro}

The international position of a currency is directly determined by the scale and manner of fulfilment of classic currency functions in the international context. Creation of the Economic and Monetary Union and the introduction of a new currency (euro) - even though the decision was strictly political - was well-received by entities of contemporary international economy, including its main participants and the players on the international currency market. The reason for such a reception was the potential of the economies in the euro area, and also structural conditions and expectations for creation of an international currency that was to be a real alternative to the US dollar. The possibility of diversification in the investment and reserve spheres as well as in reference, intervention, transfer and invoicing spheres was considered as a step in the right direction to limiting the domination of the US dollar on the market. Notwithstanding the increasing problems in euro area in the fiscal sphere and the real economy, particularly with the job market, one may agree that the latest economic crisis did not change the bipolar character of the international monetary system still based on the US dollar and the euro. However, it needs to be stressed that the euro remains rather a regional than a global currency.

Keywords: monetary integration, currency, euro, international currency position

\section{L'influence de la crise économique sur la position internationale de l'euro}

La position internationale d'une monnaie est directement déterminée par l'ampleur et les modalités de réalisation de ses fonctions classiques à l'international. La création de l'Union économique et monétaire et l'introduction d'une nouvelle monnaie (euro) - même si la décision était strictement politique - ont été bien reçues par les entités de léconomie internationale contemporaine, y compris ses principaux participants et les acteurs sur le marché international des devises. La raison d'une telle réception était le potentiel des économies nationales de la zone euro, ainsi que les conditions structurelles et les attentes pour la création d'une monnaie internationale qui devait être une véritable alternative au dollar américain. La possibilité de diversification dans les domaines d'investissement et 
de réserve ainsi que dans les domaines d'intervention, de transfert et de facturation a été considéré comme un pas dans la bonne direction pour limiter la domination du dollar américain sur le marché. Malgré les problèmes croissants dans la zone euro sur le plan fiscal et léconomie réelle, en particulier avec le marché de l’emploi, on peut convenir que la dernière crise économique na pas modifié le caractère bipolaire du système monétaire international fondé sur le dollar et l'euro. Cependant, il faut souligner que l'euro reste une monnaie régionale plus qu'une globale.

Mots-clés: l'intégration monétaire, la monnaie, l'euro, la position de monnaie internationale

\section{Влияние экономического кризиса на международную позицию евро}

международное положение валюты напрямую зависит от масштаба и способа выполнения классических функций валюты в международном контексте. Создание Экономического и валютного союза и введение новой валюты (евро), - даже при том, что это решение было чисто политическим, - было хорошо встречено субъектами современной международной экономики, в том числе ее основными участниками и игроками на международном валютном рынке. Причиной такого приема является потенциал экономик в еврозоне, а также структурные условия и ожидания связанные с созданием международной валюты, которая должна была стать реальной альтернативой доллару США. Возможность диверсификации в сфере инвестиций и резервов, а также относящейся к справочной деятельности, интервенционным действиям, трансферту и выставлению счетов, считалась как шаг в правильном направлении к ограничению господства американского доллара на рынке. Несмотря на растущие в еврозоне проблемы в налогово-бюджетной сфере и в реальном секторе экономики, в частности на рынке труда, можно сказать, что последний экономический кризис не изменил биполярного характера международной валютной системы, основанной на долларе США и евро. Тем не менее, необходимо подчеркнуть, что евро остается более региональной, чем мировой валютой.

Ключевые слова: валютная интеграция, валюта, евро, международное положение валюты 